\title{
Toward an Islamic Conception of Democracy: Islam and the Notion of Public Reason
}

\author{
RAJA BAHLUL*
}

In recent decades Islamic political thinkers have begun to take a strong interest in democratic thought and politics. Their discussions have progressed beyond the naïve and superficial task of finding expressions, taken from traditional Islamic political thought and practice, that can be used to translate modern democratic idioms (e.g., 'shura' and 'democracy'). Many of them are discussing some of the most difficult, interesting, and characteristic subjects of theoretical democratic discourse such as secularism, pluralism, popular sovereignty, individual rights, and freedom of expression.

In the present article I focus on the concept of public reason. This concept has come to occupy an important place in Western discussions of democratic decision making but has yet to be discussed adequately by Islamic thinkers. I intend to ascertain Islamic views and reactions to the notion of public reason as this has been developed in the writings of John Rawls and others. I also discuss concepts of reason in Islamic discourses, including the notion of an 'Islamic public reason.' This discussion ought to be viewed as part of an effort to discover a common language in terms of which Islamic and democratic discourses can be seen to be mutually intelligible, or at least not completely 'incommensurable.' This is a complex undertaking that entails discussing questions about constitutionalism (rule of law), civil society, popular sovereignty, secularism, freedom and equality. These (difficult) questions cannot be discussed simultaneously in a brief space. Therefore, I shall allude to them only insofar as they concern the relation between democracy and public reason.

\section{Public Reason and Democracy}

Most social scientists agree that politics is a public matter, in the sense that the issues that call for political decision are typically matters of public concern. This

\footnotetext{
* Raja Bahlul is in the Department of Philosophy and Cultural Studies' MA Program in Democracy and Human Rights, Birzeit University, Palestine. The author thanks DAAD for a grant that enabled him to stay in Berlin during the summer of 2001. He also wishes to express his gratitude to Professors Dale F. Eickelman and Armado Salvatore and to anonymous Critique referees for comments and suggestions for improvement.
} 
applies also to the method that is used to arrive at political decisions. At least in theory, democracy describes the political behavior of free and equal individuals. Such individuals presumably will have a strong interest in both the substance and method of the decisions that can affect their well-being. ${ }^{1}$

Voting, referenda, and majority rule constitute important elements of the process of democratic decision making. But alongside these, democratic theory and practice always have included a space for discussion and debate at both public and government levels. According to some thinkers, it is precisely this, rather than majority rule as such, that makes democracy attractive. Thus, according to John Dewey:

Majority rule, just as majority rule, is as foolish as its critics charge it with being. But it never is merely majority rule... The means by which a majority comes to be a majority is the more important thing: antecedent debates, modification of views to meet the opinions of minorities. ... The essential need, in other words, is the improvement of the methods and conditions of debate, discussion and persuasion. ${ }^{2}$

But how should public issues be discussed? What rules should be adhered to in the discussion? In recent years, Rawls has emerged as one of the strongest and best-known advocates of the view that we must not base our contribution to public discussion on our special 'comprehensive' (religious or philosophical) doctrines. Our contribution should be guided by what he calls 'the ideal of public reason,' which is

[T] he ideal that citizens are to conduct their public political discussions of constitutional essentials and matters of basic justice within the framework of what each sincerely regards as a reasonable political conception of justice, a conception that expresses political values that others as free and equal also might reasonably be expected reasonably to endorse. ${ }^{3}$

This conception of reason must be distinguished from mere intelligence, the capacity to acquire and use knowledge of causes and means needed for achieving predetermined goals (or 'means-ends rationality'). A capacity of the latter sort can be found in the psychopath, but such an individual would not count as a reasonable person, nor would his thinking follow the rules of public reason, in Rawls's sense.

Far from being purely instrumental and without content, public reason, according to Rawls, is based on a concept of political justice that is 'broadly liberal in character':

The content [of public reason] is formulated by a political conception of justice, which ... is liberal in character. ... [I]t specifies certain basic rights, liberties, and opportunities; ... it assigns a special priority to these rights, liberties, and opportunities;

\footnotetext{
${ }^{1}$ For a discussion of the public and private aspects of politics, see Jon Elster, 'The Market and the Forum: Three Varieties of Political Theory,' in James Bohman and William Rehg, eds., Deliberative Democracy: Essays on Reason and Politics (Cambridge: MIT Press, 1997), pp. 3-33.

2 John Dewey, The Public and its Problems, cited in Jürgen Habermas, Between Facts and Norms (Cambridge, MA: MIT Press), p. 304.

${ }^{3}$ John Rawls, Political Liberalism (New York: Columbia University Press, 1993), p. 1.
} 
and ... it affirms measures assuring all citizens adequate all-purpose means to make effective use of their basic liberties and opportunities. ${ }^{4}$

But this is not the whole picture. As citizens engage in argument and justification, they follow 'guidelines of inquiry that specify ways of reasoning and criteria for the kinds of information relevant for political questions.' To be more specific,

[W]e are to appeal only to presently accepted general beliefs and forms of reasoning found in common sense, and the methods of conclusions of science when these are not controversial.... We are not to appeal to comprehensive religious and philosophical doctrines, ... nor to elaborate economic theories of general equilibrium, say, if these are in dispute. As far as possible, the knowledge and ways of reasoning that ground our affirming the principles of justice ... are to rest on the plain truths now widely accepted, or available, to citizens generally. Otherwise the political conception would not provide a public basis of justification. ${ }^{5}$

In addition to public reason thus explained, Rawls recognizes the existence of 'nonpublic' reasons- 'the reasons of churches and universities and other associations in civil society. ${ }^{6}$ Since an understanding of the contrast between public and non-public reason will shed light on both, let us ask what is meant by 'the reason of churches.' This hopefully will take us a step toward an understanding of 'religious reason.'

A first approximation to the answer can be reached by following Robert Audi's definition of 'secular reason' as:

one whose normative force, i.e., its status as a prima facie justificatory element, does not evidentially depend on the existence of God (or denying it) or on theological considerations, or on the pronouncements of a person or institution qua religious authority. ${ }^{7}$

Clearly, Audi is not using 'reason' in the sense of a capacity to think within a certain framework of categories and guidelines, which is what Rawls's usage requires. Rather, Audi's reason is simply a consideration, a 'reason-why,' perhaps even a whole argument in support of a certain claim.

We can build on what Rawls and Audi say in order to define what we mean by 'religious reason.' In common with other types of reason, religious reason does (or ideally can) accept principles of logic, mathematics, noncontroversial science, and common-sense knowledge. However, it is distinguished from other types of reason in that it involves belief in the divine, the affirmation of theological propositions, or the pronouncements of persons and

\footnotetext{
${ }_{5}^{4}$ Ibid., p. 223.

${ }^{5}$ Ibid., pp. 224-225. Rawls also recognizes a wide notion of public reason according to which non-public reasons may be introduced as additional support for public reasons. Ideally speaking, however, public reasons ought to be sufficient for purposes of justification. For a discussion of the notion of wide (or inclusive) public reason, see David Reidy, 'Rawls' Wide View of Public Reason: Not Wide Enough,' Res Publica, 6 (2000): 49-72; and Lawrence B. Solum, 'Inclusive Public Reason,' Pacific Philosophical Quarterly, 75 (1994): 217-31.

${ }^{6}$ Rawls, Political Liberalism, p. 213.

${ }^{7}$ Robert Audi, 'Liberal Democracy and the Place of Religion in Politics,' in Robert Audi and Nicholas Wolterstorff, eds., Religion in the Public Square: The Place of Religious Convictions in Political Debate (Lanham, MD: Rowman \& Littlefield, 1997), p. 26.
} 
institutions qua religious authority. It also includes values, conceptions of good, rights, and duties ordered in a certain way. In principle, religious reason should be thought of as having 'content,' albeit one that is different from the liberal content in Rawls's public reason.

\section{Meanings of 'Reason' in Islamic Discourses}

It is possible to distinguish a number of meanings of 'reason,' as the term is used in contemporary Islamic discourses. Some meanings do not have any direct or obvious relevance to politics, and thus may be set aside. They include Mohammad al-Jabiri's use of 'reason' to mean (culture-specific) epistemological presuppositions. ${ }^{8}$ The same applies to the use of 'reason' to mean 'philosophy of rationalism,' which implies belief in the possibility of objective knowledge ${ }^{9}$ and the intelligibility of the world as a whole. ${ }^{10}$ Finally, one can mention the use of 'reason' to refer to 'instrumental rationality'-the ability to find means for achieving prescribed ends. ${ }^{11}$

However, contemporary Islamic discourses know other concepts of reason that have political implications and thus are relevant to discussing Rawls's public reason. This applies to at least two concepts that some writers have begun to discuss. The first of these addresses concerns that have moved Western thinkers to speak of 'discourse ethics.' In al-Bahth 'an al-'Aql (In search of reason), Mohammad Farhat distinguishes between 'polemics' and 'genuine dialogue,' saying that the latter presupposes a readiness to accept an opponent's view if it proves to be true. ${ }^{12}$ To improve the quality of dialogue, Farhat suggests the use of clear definitions and calls for controlling emotions that can be aroused by discussion of sensitive issues such as religion. ${ }^{13}$

Another writer, Abdel-Qadir al-Shaikhaly, has a more elaborate view of the rules that ought to govern debate. In his Akhlaqiyyat al-hiwar (Ethics of debate), he discusses the formal requirements that must be met in order for dialogue to be fruitful. These include 'good conversational manners,' such as listening attentively to one's opponent, and avoidance of anger and personal attacks. More importantly, the manners include having an attitude of respect toward the other person, a measure of healthy skepticism concerning the truth, and readiness to support a position with reasons and arguments. ${ }^{14} \mathrm{Al}$-Shaikhaly is aware that civil public debates are taking place all the time in democratic countries and that such

\footnotetext{
${ }^{8}$ Mohammad al-Jabiri, Takwin al-'qal al-'Arabi [The constitution of the Arab mind] (Beirut: Markaz Dirasat al-Wihdah, 1991), p. 15.

${ }^{9}$ Burhan Ghallion, 'Al-'Aqlaniyyah wa Naqd al-'Aql' [Rationalism and the critique of reason'], al-Wihdah (1988): 93-94.

${ }^{10}$ Mohammad Jassous, 'Jadaliyyat al-'Aql wa al- 'Aqlaniyyah' [Dialectic of reason and rationality], al-Wihdah (1988): 32.

${ }^{11}$ Ibid., p. 39; cf. Ghallion, 'Al-'Aqlaniyya,' p. 104; and al-Jabiri, Takwin, p. 24.

${ }^{12}$ Mohammad Farhat, Al-Bahth 'an al-'Aql [In search of reason] (Cairo: Dar al-Hilal, 1997), p. 7.

${ }^{13}$ Ibid., p. 8.

${ }^{14}$ Abdel-Qadir al-Shaikhaly, Akhlaqiyat al-hiwar (Ethics of Debate) (Amman: Dar al-Shorouq, 1993), pp. 16, 22, 43.
} 
debates contribute to the vitality of political life in a democracy. He is convinced of the need for something similar to happen in Islamic countries. ${ }^{15}$ However, he does not go into the details of the hoped-for political order, nor does he discuss the types of justifications (religious or non-religious) that may be used legitimately in public debates.

The second concept of reason that has become an object of much discussion is 'Islamic reason.' This is, of course, a type of religious reason. Several writers have commented critically on this type of rationality. For example, 'religious rationality' (al-'aqlaniyah al-diniyyah) is the term that the well-known Arab sociologist Halim Barakat uses to refer to the rationality of the various Islamic 'religious sciences,' e.g., Qur'anic exegesis and jurisprudence. According to Barakat, Islamic religious rationality is based on traditional faith and the use of logical and legal methods such as precedent and reasoning by analogy (al-qiyas). ${ }^{16}$ Clearly, this type of reasoning need not be restricted to the religious sciences. Religious-minded thinkers do not necessarily change their methods of reasoning when they discuss political and other public matters.

Another writer with a clear conception of the 'Islamic method of reasoning' is Nasr Hamid Abu-Zayd. His Naqd al-Khitab al-Diniy (Critique of religious discourse) offers an analysis of the principles that govern Islamic discourse, including one principle that he contentiously calls 'reduction of all phenomena to one source.' 17 Not surprisingly, the author finds Islamic reason narrow, intolerant, and reductionist.

Munir Shafiq probably has provided the clearest and most relevant conceptualization of 'Islamic reason.' Struggling with skepticism and anxious to overcome a supposed dichotomy between reason and faith, Shafiq argues that there is no single 'reason' that either can support or oppose faith:

We must once and for all put an end to the fallacy which is implicit in the questions of 'What is compatible with reason? What is compatible with faith?' For the correct approach is to ask 'What is compatible with reason which is based on Islam, as opposed to reason which is based on other faiths?' The conflict is not between reason and irrationality. Rather, it is between categories which are championed by different minds. ${ }^{18}$

Shafiq's meaning is clear, but it would be even clearer if his last sentence were to be understood as meaning that the conflict is between different rationalities, or types of reason, that are espoused by different people. In any case, the crucial term here is 'reason which is based on Islam,' or 'Islamic reason.'

Islamic reason does not differ generically from other types of reason. It does, however, incorporate distinctive beliefs in the areas of metaphysics, religion, and morality. In other words, reason that is based on Islam has 'content,' and it

\footnotetext{
${ }^{15}$ Ibid., pp. 90-91.

${ }^{16}$ Halim Barakat, 'Al-'Aqlaniyah wa al-Mukhailah fi al-thaqafah al-'Arabiyyah' [Rationality and imagination in Arab culture], al-Wihdah (1988): 51.

${ }^{17}$ Nasr Hamid Abu-Zayd, Naqd al-Khitab al-Diniy [Critique of religious discourse] (Cairo: Sina lil-Nashr, 1994), p. 67.

${ }^{18}$ Munir Shafiq, Islam in the Struggle for Civilization (Tunis: Dar al-Buraq, 1991), p. 138, emphasis added.
} 
should be thought of in general terms by analogy to 'reason that is based on a liberal political conception of justice.' In both cases there are principles and values that constitute the ground rules for the discussion of public matters. What these matters are and whether they are 'off-limits' to public discussion are questions whose answers depend on one's interpretation of the shari'a. We do not need to resolve these questions in order to see the prima facie intelligibility of the notion of Islamic reason. ${ }^{19}$

In concrete terms, what does it mean to use Islamic reason to think about public matters? In recent years, Islamic approaches and methods of analysis have proliferated to such an extent among the educated, or 'arguing' groups, within Muslim societies that it could be said that Islamic reason rapidly is becoming the dominant mode of thinking about public matters. Hence it may not seem difficult to provide examples of such use. However, this Islamic public argument is not taking place in stable, well-established Islamic polities, with society-wide intellectual traditions and unquestioned legitimacy. Thus, it may prove difficult to find realistic examples of the operation of 'Islamic reason.' Still, one or two examples come to mind.

The first example is a form of public criticism that Talal Asad has discussed in connection with the (Islamic?) regime of Saudi Arabia. Nasiha, or 'morally corrective criticism,' is addressed to rulers or to society at large, and often is delivered publicly during Friday sermons or by means of theological lectures that are circulated widely among the reading and viewing publics. According to Asad, nasiha is a form of 'reasoned criticism,' and the authority with which the nasiha-givers (the 'ulema) speak is subject to 'conceptual and institutional conditions that must be attended to if discourses are to be persuasive.' 20

In one respect, the practice of nasiha resembles what Kant calls 'the public use of reason.' To those who practice it, nasiha does not express private opinion or private taste. It is more like the use that anyone may make of his reason 'as a man of learning addressing the entire reading public. ${ }^{21}$ Yet in another respect nasiha is not egalitarian, for it implies that the ruler or other persons at the receiving end of the nasiha are not the moral equals of the nasiha-giver. According to Asad,

nasiha ... stand[s] in a conceptual world quite unlike that of the Enlightenment. For unlike the former, the latter world is inhabited by individuals aspiring to selfdetermination and dispassionate judgment, whose moral foundation is universal reason, not disciplined virtues. ${ }^{22}$

\footnotetext{
${ }^{19}$ A useful classification of the different approaches to shari' $a$, with illustrative examples drawn from the works of several Islamic scholars, can be found in Charles Kurzman, ed., Liberal Islam: A Sourcebook (Oxford: Oxford University Press, 1998), pp. 14-17.

${ }^{20}$ Talal Asad, 'The Limits of Religious Criticism in the Middle East: Notes on Islamic Public Argument,' in idem, Genealogies of Religion: Discipline and Reasons of Power in Christianity and Islam (Baltimore: Johns Hopkins University Press, 1993), p. 210. Part of what the author means to refer to is the 'Islamic content' of the nasiha; but this is not to be taken as objection, inasmuch as a corresponding 'ideological' content can be attributed to reasoning that takes place within the confines of the modern liberal tradition (see ibid., p. 236).

${ }^{21}$ Kant, Political Writings, ed. Hans Reiss (Cambridge: Cambridge University Press, 1970), p. 55.

${ }^{22}$ Asad, 'The Limits of Religious Criticism in the Middle East: Notes on Islamic Public Argument,' pp. 219-20.
} 
Still, it may be argued that this inegalitarianism is not a consequence of the Islamic faith as such, but is a product of Islamic history and the activities of the politically ambitious "ulema. One certainly can imagine a more enlightened and egalitarian Islamic polity where freedom of thought and expression allows nasiha to be both universal and mutual, instead of being a privilege of a specific class of people with a monopoly of religious knowledge.

Perhaps certain aspects of this imagined ideal eventually will be realized in the Islamic Republic of Iran. Of course, few, if any, people believe that contemporary Iran is an ideal Islamic polity, but it is probably the only regime with serious Islamic credentials that has managed to sustain continued disagreements and debates among people who profess to stand on Islamic grounds. Public matters are discussed and disagreements are found among different parties, but all this takes place within a broad consensus on the need and necessity for an Islamic regime.

In such a society, public reasoning does take place, and people are expected to offer arguments for their positions. Many of these arguments will not differ from those found in other, non-Islamic societies. ${ }^{23}$ But there will be differences, connected to the use of 'religious reason': Periodically, we shall come across an argument whose major premise is a Qur'anic verse, a tradition of the Prophet, or something that has uncontested religious authority. Parties to a debate will not reject the use of such premises. Rather, they will attack other parts in the argument, or they will seek to disarm the troublesome premise by offering a reinterpretation that will render it irrelevant to the conclusion.

To reiterate: Reasoning does take place here, and it takes place in public. ${ }^{24} \mathrm{But}$ is this a case of public reasoning? Certainly it is not in Rawls's sense of the term. We may ask 'why not'? Is the meaning that Rawls attaches to public reason the only legitimate one? Does public reason have to be secular? These questions bring us face to face with the challenges that public reason (in Rawls's sense) encounters in Islamic societies, where religious reason is well entrenched.

\section{Community, Diversity, and Public Reason}

According to Rawls, one of the most important questions that political theory should seek to answer is:

How is it possible that there may exist over time a stable and just society of free and equal citizens profoundly divided by reasonable though incompatible religious, philosophical, and moral doctrines? $?^{25}$

\footnotetext{
${ }^{23}$ Universal human needs and possibilities will dictate certain propositions for all societies, just as they will exclude others.

${ }^{24}$ Many complex questions remain to be discussed in connection with the relations between civil society, the public sphere, the state, and society in general. For a discussion of 'Islamic public spheres,' see Dale Eickelman and A. Salvatore, 'The Public Spheres and Muslim Identities,' European Journal of Sociology, XLIII (2002): 92-115; for a discussion of different views on the relation between democracy, the Islamic state, and society, see Yahya Sadowski, 'The New Orientalism and the Democracy Debate,' in Joel Beinin and Joe Stork, eds., Political Islam: Essays from Middle East Report (London: I. B. Tauris, 1997).

${ }^{25}$ Rawls, Political Liberalism, p. xx.
} 
Rawls takes his theory of political liberalism to provide an answer to this question. In this he does not differ from other thinkers who view liberalism as a solution to the problem of government amid diversity. Thus Wolterstorff says:

Liberal democracy is in good measure a mode of governance relevant to those societies in which different religions are represented, and not only different religions, but different comprehensive perspectives on reality, the good life, and human destiny. ${ }^{26}$

This characterization of liberalism does not explain why we need to develop a conception of public reason that is based on a liberal political conception of justice. The bridge to such a conception is established partly through what Rawls calls 'the liberal principle of legitimacy.' According to this principle:

[O]ur exercise of political power is proper and hence justifiable only when it is exercised in accordance with a constitution the essentials of which all citizens may reasonably be expected to endorse in the light of principles and ideals acceptable to them as reasonable and rational. ${ }^{27}$

Why would it be wrong to exercise political power over people in accordance with rules and constitutions which they do not understand, or which they understand, but deeply disagree with? According to Charles Larmore, 'we shall be treating persons merely as means, as objects of coercion, and not also as ends, engaging in directly their distinctive capacities as persons. ${ }^{28}$ Thus, it appears that the ultimate reason that lies behind the liberal principle of legitimacy is the principle of respect for persons. ${ }^{29}$

The same notion of 'respect for persons' underlies 'the duty of civility,' which enjoins citizens to 'explain to one another on those fundamental questions how the principles and policies they advocate and vote for can be supported by the political values of public reason. ${ }^{30}$ This brings us close to forming a conception of public reason in accordance with Rawls's criteria. For the use of reasons that others (can) understand leads to the notion of reason being 'public' in the sense of not presupposing unfamiliar or controversial methods and doctrines. Given that 'religious reasons' are almost invariably controversial and non-universal, they are immediately driven out from the public arena. They are not fit material for public reasoning. ${ }^{31}$

\footnotetext{
${ }^{26}$ Nicholas Wolterstorff, 'The Role of Religion in Decision and Discussion of Political Issues,' in Audi and Wolterstorff, eds., Religion in the Public Square: The Place of Religious Convictions in Political Debate, p. 69; cf. Audi, 'Liberal Democracy,' p. 16.

${ }^{27}$ Rawls, Political Liberalism, p. 217.

${ }^{28}$ Charles Larmore, 'The Moral Basis of Political Liberalism,' Journal of Philosophy, XCVI (1999): 607; cf. Jean Hampton, 'The Common Faith of Liberalism,' Pacific Philosophical Quarterly, 75 (1994): 194.

${ }^{29}$ Larmore, 'The Moral Basis of Liberalism,' p. 607.

${ }^{30}$ Rawls, Political Liberalism, p. 217.

${ }^{31}$ According to Onora O'Neill, 'A communication that presupposes some authority other than that of reason may fail to communicate with those who are not subject to that authority; they can interpret it, if at all, only on the hypothesis of some claim that they reject.' See Onora O'Neill, 'The Public Use of Reason,' in The Constructions of Reason (Cambridge: Cambridge University Press, 1989), p. 34.
} 
From an Islamic point of view (shared by many non-Islamists as well), this method of justifying public reason has one serious limitation. It is based on the supposition of doctrinal diversity, the irreducible plurality of comprehensive doctrines in society. But what if there is a society that is more or less doctrinally homogeneous, united by belief in a certain religion? Here, one no longer would need to worry about communication failures if religious reason were to be allowed to work in the public sphere. Nor would one need to worry about acting disrespectfully toward fellow citizens, because religious reasons would be common currency in this type of society.

Many Islamic thinkers are attracted to this line of argument, for they tend to believe that Islamic peoples, commonly taken to constitute one umma (nation), have the same conceptions of justice and goodness. Hence they expect Islamic political life to be less adversarial and more consensual than in other communities. Of course, this is by no means obvious. Attention may be drawn to the various schools of thought that have flourished since the beginning of the Arab Renaissance in the second half of the nineteenth century. These schools included Islamism, secular nationalism, socialism, liberalism, communism and pan-Arabism. It is true that many of these ideologies have lost much ground to Islamism, which has become the dominant mode of thought in recent years. However, it is always possible that a situation of diversity may arise again.

Be that as it may, it is not clear that the attempt to base (Rawlsian) public reason on the assumption of doctrinal diversity can yield definitive results. For Islamic thinkers may be able to admit the existence of a certain measure of doctrinal diversity in contemporary Islamic societies and still make a case for Islamic reason. Their argument can take the following form. All societies, past and present, have known doctrinal diversity. The question is never whether doctrinal diversity exists, but whether it is wide enough to rule out the possibility of political community. Now, in order for people to be able to live together as one political community, they must agree on some basic things. They cannot disagree over the most important issues and principles of social-political life and continue to exist for long as one political community. Therefore the pluralism and doctrinal diversity (of which Rawls and other liberal thinkers speak) must be limited by general agreement on fundamental matters. What these fundamentals are (whether they are liberal or Islamic, secular or religious) will differ from one society to another. They cannot be decided a priori by philosophers. In the end it is people themselves who must choose their own constitution.

This limitation on doctrinal diversity applies to all political communities, including those best suited to the application of Rawls's notion of public reason. Some commentators have recognized this point; for example, according to Wolterstorff:

What is striking about our contemporary proponents of the liberal position is that they are still looking for a politics that is the politics of community with shared perspective. They see that perspective cannot, in our societies, be a comprehensive perspective ... So they propose scaling down our expectations. Take a society that is more less a liberal 
democracy, and then consider a single aspect of that society, a single dimension: the political. $^{32}$

Indeed, how else is one to think of Rawls's idea that

[C]itizens who affirm reasonable but opposing comprehensive doctrines belong to an overlapping consensus: that is, they generally endorse that conception of justice as giving the content of their political judgments on basic institutions. ... In such a consensus, the reasonable doctrines endorse the political conception, each from its own point of view. ${ }^{33}$

Aren't people who endorse the same political conception of justice a 'community' of sorts (a community with 'shared perspective')? This concept of community may not be robust enough to satisfy communitarians, but it is probably 'thicker' than the concept that Wolterstorff thinks is sufficient for politics. Onora O'Neill also has dwelled on 'communal' aspects of Rawls's theory, claiming that

In assuming an idealized, closed society ... as the context of political justification, Rawls takes it that the public who are the proper audience for one another's attempts at justification consists of fellow citizens, among whom there is in effect prior understanding that they form a 'people. ${ }^{34}$

Community being unavoidable, the question that remains is what sort of community is it, or how is it constituted ideologically? For instance, will an Islamic society opt for a liberal political conception of justice and the notion of public reason on which it is based? Or will it opt for an Islamic conception of justice and the Islamic reason on which it is based?

The argument that the former path should be taken on account of doctrinal diversity has to meet two challenges. Firstly, advocates of liberal public reason have to show that doctrinal diversity exists to a politically relevant degree. Secondly, they have to explain why the political community formed out of the doctrinal diversity has to follow a liberal political conception of justice, rather than an Islamic or some other conception. Is the liberal conception preferable to other candidates because of its neutrality? Or is it preferable because all ('reasonable') comprehensive doctrines are able to accept it, 'each from its point of view,' as Rawls claims?

\section{The Dogmatic Aspect of Public Reason}

Debates that are taking place in the West between communitarian and liberal proponents of democracy have yet to make an impact on Islamic thinkers who continue to think of democracy mainly in liberal versus socialist terms. Nevertheless, there are two reasons for making reference to the debate between liberals and communitarians here. Firstly, the debate is relevant to the critique of the

\footnotetext{
${ }^{32}$ Wolterstorff, 'The Role of Religion,' p. 109 (emphasis added).

${ }^{33}$ Rawls, Political Liberalism, 39, pp. 39, 134.

${ }^{34}$ Onora O'Neill, 'Political Liberalism and Public Reason: A Critical Notice of John Rawls, Political Liberalism,' Philosophical Review, 106 (1997): 419.
} 
Rawlsian conception of public reason and the liberal conception of justice on which it is based. Secondly, and more importantly, some of the Islamic objections to the notion of public reason are formulated best in communitarian terms.

According to Hillary Aronovitch, the philosophical core of communitarianism consists of these two ideas: firstly, the notion of the encumbered (socially situated) self, whose sense of identity is bound up with certain values, beliefs and practices; and, secondly, the priority of the idea of good to the idea of rights. ${ }^{35}$ There is much here with which Islamic thinkers can agree, which can be used to criticize some of the presuppositions of the notion of public reason, as understood by Rawls. ${ }^{36}$

Let us first take up the matter of the 'encumbered self' in relation to public reason. According to this conception, public reason is the language of communication that citizens use to address each other as free and equal persons, without reference to moral, philosophical, or religious beliefs. This is how citizens appear in public. This is their public identity, so to speak. But over and above their public identity citizens are allowed to have a non-public identity that Rawls describes in these terms:

It is essential to stress that citizens in their personal affairs, or in the internal life of associations to which they belong, may regard their final ends and attachments in a way very different from the way the political conception involves.... They may regard it simply unthinkable to view themselves apart from certain religious, philosophical and moral convictions, or from certain enduring attachments and loyalties. These convictions and attachments are part of what we may call their 'nonpublic identity. ${ }^{37}$

In other words, one is allowed to have two identities. Qua political person, one is obliged to reason in accordance with the precepts of public reason, to have a 'highest-order interest' in the capacity for autonomy; qua private citizen one is allowed to be, say, a believer who uses religious, rather than public, reason in his dealings with the world.

Islamic thinkers reject the prospect of viewing persons as either "private citizens' or 'political citizens.' To them, the correct classification is one that distinguishes between believers and non-believers. Religious belief is politically relevant. Not only that, but it also plays an integrative function that resists all attempts to turn religion into a private matter. To get an idea about how

\footnotetext{
${ }^{35}$ Hillary Aronovitch, 'From Communitarianism to Republicanism: On Sandal and His Critics,' Canadian Journal of Philosophy, 30 (2000): 621.

${ }^{36}$ Fred Halliday states in 'Relativism and Universalism in Human Rights: The Case of the Islamic Middle East,' in Politics and Human Rights, ed. David Beetham (London: Blackwell, 1987), p. 155, that it is a simplification to compare the Islamic position in the human rights debate to the communitarian views encountered in Western thought. However, it is not obvious that the comparison is altogether misguided. Religious communities experienced the priority of the good to the right, and their members lived as 'encumbered selves' long before they could describe their experiences in these terms. Quite to the contrary, it could be said that modern communitarian conceptions, including some that are secular, derive their inspiration from visions that religious communities sought to realize.

${ }^{37}$ John Rawls, 'Justice as Fairness: Political Not Metaphysical,' Philosophy and Public Affairs, 14 (1985): 241.
} 
'encumbered' is the Islamic self, consider what al-Mawdudi, a well-respected modern Islamic thinker, says about the role that shari' $a$ plays in the life of the Muslim individual:

[Shari'a] judgments of good and evil extend to all parts of our lives. They cover religious acts and duties, as well as actions undertaken by individuals that reflect on their way of life, morals, customs, manners of eating, drinking, attire, speech, and family affairs. They cover social relationships, financial, economic and administrative matters, rights and duties of citizenship, organs of government, war and peace, and relations with foreign powers ... There is no part of our lives where the shari'a does not distinguish between good and evil. ${ }^{38}$

In Rawls's system, believers are expected to bracket religious teachings and injunctions when they step into the public arena. They are to act as if religion does not matter to the way one relates to other citizens. But what kind of self is that which self-consistently can switch between two identities-at one moment thinking that religious beliefs and values are the most important things in life, the next moment acting as if they did not matter?

Like other Western thinkers who have criticized this part of Rawls's theory, Islamic thinkers are likely to follow Will Kymlicka in wondering about the coherence of this position:

The problem is to explain why anyone would accept the ideal of autonomy in political contexts without also accepting it more generally. If the members of a religious community see their religious ends as constitutive, so that they have no ability to stand back and assess these ends, why would they accept a political conception of the person that assumes that they do have that ability (and indeed a highest-order interest in exercising that ability)? ${ }^{39}$

Rawls's conception of the place and function of religious identity is not the only objectionable part of his theory. Many Islamic thinkers also will have problems with his claim of the priority of the idea of right over good. This is another side of the individualist-contractarian spirit that animates Rawls's political liberalism and its associated concept of public reason. Both can be seen at work in the notion of the 'original position.'

As it is commonly explained, Rawls's 'original position' is a method of reasoning about the ideas of equality, freedom, and autonomy in an imaginary setting where individuals are denied all knowledge that might prejudice their conclusions about rights and obligations. Reasoning about rights in the original position leads to the two well-known principles of justice: the principle that gives each person equal basic liberty consistent with equal basic liberty to all; and the difference principle which ensures that each citizen has the material

\footnotetext{
${ }^{38}$ Mawdudi, Al-Qanun al-Islami wa Turuq Tanfithih [Islamic law and methods of its application] (n.p.: Mu'assasat al-Risalah, 1975), p. 24.

${ }^{39}$ Will Kymlicka, 'Two Models of Pluralism and Tolerance,' in Toleration: An Elusive Virtue, ed. David Heyd (Princeton: Princeton University Press, 1996), p. 91.
} 
means necessary for exercising his or her basic liberty. These two principles shape the 'content' of public reason. ${ }^{40}$

But what does the priority of right to the good amount to? This is explained by reference to the above-mentioned two principles. According to Rawls:

In justice as fairness the priority of right means that the principles of political justice impose limits on permissible ways of life; and hence the claims citizens make to pursue ends that transgress those limits have no weight. ${ }^{41}$

The idea is that free and equal individuals may have different views about the good (life). Individuals have a right to pursue their own conception of the good to the extent that their 'way of life' does not threaten the right that other individuals have to pursue their own possibly different ends. Rights are 'fixed,' as it were, and they cannot be overturned in the name of any good. Political society is thus conceived of as a contractual association of separate, autonomous individuals who stand on their rights, and who are united mainly by their belief in the desirability of living as separate, autonomous individuals.

Islamic thinkers respond to this vision in two ways. Firstly, they offer a vision of society that does not consist of separate, free individuals who have a highest interest in autonomy. Society is conceived of as a large, integrated project the purpose of which is to realize a supreme human good, which is for the individual to stand in the right relationship to God. To stand too much on one's rights and to insist too much on one's autonomy and freedom are taken as signs of putting the self (instead of God) at the center of one's life. In the Islamic vision there is no room for autonomous, free individuals to 'negotiate' a social-political scheme that is designed to preserve their freedom and autonomy to the greatest possible extent. Rather, there is a division of labor, an assignment of roles with different rights and duties that may not be equal but which nevertheless are accepted as the right moral scheme.

Aside from this, Islamic thinkers can claim that liberalism does not really succeed in putting the notion of the good in second place, despite its claim to the contrary. This can be seen when we consider the rights and liberties that are enshrined in Rawls's first principle of justice, which says:

Each person has an equal claim to a fully adequate scheme of equal basic rights and liberties, which scheme is compatible with the same scheme for all; and in this scheme the equal political liberties, and only those liberties, are to be guaranteed their fair value. $^{42}$

It is interesting to observe that only political rights and liberties are guaranteed their fair value. These are the rights that protect, nurture, or otherwise help realize the ideal of the human individual as free, autonomous, and equal. But if

\footnotetext{
${ }^{40}$ Rawls, Political Liberalism, p. 223.

${ }^{41}$ Ibid., p. 174.

42 Ibid., p. 5.
} 
it were not good for humans to be free, autonomous and equal, what significance would these rights have? As Aronovitch says:

liberalism is ... committed to a good as the basis of its rights and the notion of justice, but this good is that of a certain conception of personal development, a certain sense of the self. ${ }^{43}$

This is presumably the self that is free, autonomous, and able to revise its values and commitments without loss of identity. This is certainly an ideal that many people find attractive, especially those who are skeptical of finding 'the truth' in moral and political matters. Without this ideal, the liberal scheme of rights would lose its purpose and meaning.

In this light, liberalism is seen to hide a specific conception of the good, one that belies its claim of neutrality between different conceptions of the good. In fact, one author has gone so far as to argue that Rawls's political liberalism differs very little from other traditional, supposedly 'sectarian' varieties of liberalism, which Rawls is anxious to avoid. ${ }^{44}$

Rawls's public reason can be seen to favor a certain conception of the self (autonomous, free, and unencumbered) and a certain conception of the good (the good of being a free, autonomous, and unencumbered self). The rules of reasoning, and the premises from which one is allowed to reason, are designed to support these conceptions. In view of these considerations, it may be better to refer to Rawls's public reason as liberal public reason, which is indeed how some authors refer to it. ${ }^{45}$ For Rawls to speak of 'public reason,' pure and simple, is presumptuous, because it implies that only by being based on (political) liberalism can reason be public. ${ }^{46}$

\section{Conclusion: Islam, Public Reason, and Democracy}

To Islamic writers the most debatable aspect of public reason is its content. If it is stipulated initially that public reason means reasoning on the basis of a liberal political conception of justice, then Islamic thought easily proves to be antithetical to public reasoning. By Rawls's definition, Islam is a comprehensive doctrine, which means it cannot serve as a ground for public reasoning. But stipulative definitions are not to the point here, nor do they prove anything. As it is, the notion of public reason does not seem to have been caught in the clutches of any stipulative definitions so far. The fact that some authors are willing to speak of 'liberal public reason' shows that we are not dealing with a tautology.

\footnotetext{
${ }^{43}$ Aronovitch, p. 635.

${ }^{44}$ Hampton, p. 187.

${ }^{45}$ Reidy, p. 52; Andrew Williams, 'The Alleged Incompleteness of Public Reason,' Res Publica, 6 (2000): 207.

${ }^{46}$ Consider what James Bohman says about this 'assumption of singularity': 'If a society is diverse and divided, there is no one "public sphere," no one public, but instead a plurality of them: the publics of different sub-groups, cultures, or experts.' (Bohman, 'Public Reason and Cultural Pluralism: Political Liberalism and the Problem of Moral Conflict,' Political Theory, 23 (1995): 260.) A pluralism of 'public reasons' is not a less plausible notion than a plurality of publics.
} 
To all appearances, the meaning and role of 'public reason' can be contested by different theories about the nature of reasoning as well as 'publicness.' To Larmore, the term 'reasonable' means 'the free and open exercise of the basic capacities of reason.' ${ }^{47}$ This does not imply the restrictions that Rawls uses to exclude reasoning from religious premises. Similarly, the concept of what is public is defined differently in different societies and cultures. Modern and traditional (secularized and religious) societies have defined the boundaries differently, and probably will continue to do so.

Putting all of these ideas together yields the conclusion that is not out of the question for non-secular views, such as Islam, to lay claim to $a$ concept of public reason. Of course, this will be an Islam-based public reason, in analogy to Rawls's liberalism-based public reason. In Rawls's case, the ideal of public reason is a reflection of certain aspects of democratic practice in contemporary Western liberal democracies. Such practice is characterized by (a certain measure of) openness, freedom, pluralism, and secularism. Thus, a question naturally will arise as to whether 'Islamic public reason' can be said to be compatible with democracy. Certainly, it cannot be said to be compatible with liberal democratic practice. But, as was the case with the notion of public reason, Islamic thinkers will want to ask whether liberal democratic practice is the only legitimate interpretation of democracy.

Several writers, Islamic and non-Islamic, have argued for the somewhat unusual (but not obviously incoherent) view that a society where religion is practiced as a public matter can be democratic. Thus, Joseph Schumpeter argues that 'Religious fervor ... is certainly compatible with democracy however we define the latter.' According to him, we have to let every populus define itself in whatever manner it chooses. ${ }^{48}$ On this account, religious self-definition is certainly possible, and thus religion may come to be practiced as a public matter (if the populus so wishes). More modestly, other writers have sought to argue that, conceptually, democracy does not imply secularism, and that, despite appearances to the contrary, popular sovereignty and divine sovereignty are not mutually exclusive. ${ }^{49}$ Still others have sought to uncover democratic elements within Islamic thought and history. ${ }^{50}$

Criticism of Islamic norms with respect to equality, toleration, pluralism, and freedom of thought are all too familiar. Some, perhaps all, of these matters are relevant to the meaning (and exercise) of public reason. Thus, if women and non-Muslims are not treated as equal citizens in the Islamic polity, serious questions will arise as to the meaning of 'public,' which will be reduced to the 'male Muslim public,' as opposed to 'public' pure and simple. Similarly, it can

\footnotetext{
${ }^{47}$ Larmore, 'The Moral Basis,' p. 602.

${ }^{48}$ Joseph Schumpeter, Capitalism, Socialism, and Democracy (New York: Harper \& Row, 1976), p. 245.

${ }^{49}$ Raja Bahlul, 'People vs. God: The Logic of “Divine Sovereignty” in Islamic Democratic Discourse,' Islam and Muslim-Christian Relations, 11 (2000): 287-98.

${ }^{50}$ John Esposito and John Voll, Islam and Democracy (Oxford: Oxford University Press, 1996).
} 
be argued that toleration and freedom of thought are necessary to the proper exercise of the reasoning faculty. ${ }^{51}$

These are difficult questions, and more work needs to be done by Islamic thinkers on these and other issues before it can be said that Islamic thought has reached a satisfactory settlement with democracy. In this connection one should mention the daring interpretations of Islamic law (shari'a) that have been presented by innovative Islamic thinkers in the areas of human rights ${ }^{52}$ and the epistemology of religious knowledge. ${ }^{53}$

It must also be remembered that questions of toleration, pluralism, and freedom of thought and expression are not problematic solely in Islamic political-cultural settings. They continue to constitute a problem for liberal government as well. For example, in one rather revealing passage, Rawls acknowledges the possibility that society may contain unreasonable, irrational, even 'mad' comprehensive doctrines (in addition to the 'reasonable' doctrines that accept 'the essentials of a democratic regime'). What is to be done about such doctrines? Rawls's uncompromising answer is that '[in] their case the problem is to contain them so that they do not undermine the unity and justice of society. ${ }^{54}$ However, 'containment' is different from toleration. It implies active resistance, if not outright hostility.

Of course, advocates of religious government will be gratified to hear liberals acknowledge that tolerance has limits. Clearly, the differences between liberal and religious rule will focus on the kinds of things to be tolerated, and the extent to which they are tolerated. Without belittling the importance of differences between different political systems, it must be admitted in the end that there are few truths in this area that have been accepted by all societies and all cultures. Thus, for example, one can expect to find differences between liberal and Islamic regimes when it comes to the toleration of 'first trimester abortions.' Such differences need not impugn the claims of either to democracy and 'reasonableness.' All they show is that ideas of what is reasonable differ from one society to another. They may even differ within one society, as evidenced by some of the criticism leveled at Rawls's (implied) claim that the anti-abortionist position is 'unreasonable.' 55

Nevertheless, despite disagreement over concepts of reason and publicness, one can see that the role which Islamic pubic reason stands to play in the Islamic polity is similar to the role which public reason (as explained by Rawls) plays in the liberal-democratic polity. Its precepts, principles, restrictions, and guidelines provide citizens with a framework of argument, so that reasonable or

\footnotetext{
${ }^{51}$ The point is made well by Kant (A738/B767): 'Reason depends on ... freedom for its very existence. For reason has no dictatorial authority; its verdict is always simply the agreement of free citizens, of whom each one must be permitted to express, without let or hindrance, his objection or even his veto.' See Kant, Critique of Pure Reason (New York: St. Martin's Press, 1965).

${ }^{52}$ Abdullahi Ahmad An-Na 'im, Toward an Islamic Reformation: Civil Liberties, Human Rights, and International Law (Syracuse: Syracuse University Press, 1990).

${ }^{53}$ Abdul-Karim Soroush, 'The Evolution and Devolution of Religious Knowledge,' in Charles Kurzman, ed., Liberal Islam: A Sourcebook (Oxford: Oxford University Press, 1998).

${ }^{54}$ Rawls, Political Liberalism, p. xix.

${ }^{55}$ Hampton, 'The Common Faith of Liberalism,' p. 209.
} 
compelling arguments may be distinguished from those that are 'unreasonable.' The differences between Islamic public reason and (liberal) public reason are obvious. As to judgments of ultimate superiority (or inferiority), they must await the resolution of ancient philosophical disagreements about truth, justice and goodness, a resolution that is not likely to happen.

\section{References}

Abu-Zayd, Nasr Hamid (1994) Naqd al-Khitab al-Diniy [Critique of religious discourse] (Cairo: Sina lil-Nashr).

Aronovitch, Hillary (2000) 'From Communitarianism to Republicanism: On Sandal and his Critics,' in Canadian Journal of Philosophy, 30, pp. 621-48.

Asad, Talal (1993) 'The Limits of Religious Criticism in the Middle East: Notes on Islamic Public Argument,' in idem, Genealogies of Religion: Discipline and Reasons of Power in Christianity and Islam (Baltimore and London: Johns Hopkins University Press).

Audi, Robert (1997) 'Liberal Democracy and the Place of Religion in Politics,' in Robert Audi and Nicholas Wolterstorff, eds., Religion in the Public Square: The Place of Religious Convictions in Political Debate (Lanham, MD: Rowman \& Littlefield).

Bahlul, Raja (2000) 'People vs. God: The Logic of "Divine Sovereignty" in Islamic Democratic Discourse,' in Islam and Muslim-Christian Relations, 11(3), pp. 287-98.

Barakat, Halim (1988) 'Al-'Aqlaniyah wa al-Mukhailah fi al-thaqafah al-'Arabiyyah' [Rationality and imagination in Arab culture], in al-Wihdah, pp. 50-57.

Bohman, James (1995) 'Public Reason and Cultural Pluralism: Political Liberalism and the Problem of Moral Conflict,' in Political Theory, 3, pp. 253-79.

Dewey, John (1954) The Public and its Problems (Chicago: Gateway Books).

Eickelman, Dale F. and A. Salvatore (2002) 'The Public Spheres and Muslim Identities,' in European Journal of Sociology, XLIII, pp. 92-115.

Elster, Jon (1997) 'The Market and the Forum: Three Varieties of Political Theory,' in James Bohman and William Rehg, eds., Deliberative Democracy: Essays on Reason and Politics (Cambridge, MA: MIT Press), pp. 3-33.

Esposito, John L. and John O. Voll (1996) Islam and Democracy (Oxford: Oxford University Press).

Farhat, Mohammad (1997) Al-Bahth 'an al- 'Aql [In search of reason] (Cairo: Dar al-Hilal).

Ghallion, Burhan (1988) 'Al-'Aqlaniyyah wa Naqd al-'Aql' [Rationalism and the critique of reason'], in al-Wihdah, pp. 89-109.

Habermas, Jürgen (1996) Between Facts and Norms (Cambridge, MA: MIT Press).

Halliday, Fred (1987) 'Relativism and Universalism in Human Rights: The Case of the Islamic Middle East,' in David Beetham, ed., Politics and Human Rights (London: Blackwell).

Hampton, Jean (1994) 'The Common Faith of Liberalism,' in Pacific Philosophical Quarterly, 75, pp. 186-216.

al-Jabiri, Mohammad (1991) Takwin al-'qal al-'Arabi [The constitution of the Arab mind] (Beirut: Markaz Dirasat al-Wihdah).

Jassous, Mohammad (1988) 'Jadaliyyat al-'Aql wa al-'Aqlaniyyah' [Dialectic of reason and rationality], in al-Wihdah, pp. 32-39.

Kant (1965) Critique of Pure Reason (New York: St. Martin's Press).

Kant (1970) Political Writings, Hans Reiss, ed. (Cambridge: Cambridge University Press).

Kurzman, Charles, ed. (1998) Liberal Islam: A Sourcebook (Oxford: Oxford University Press). 


\section{RAJA BAHLUL}

Kymlicka, Will (1996) 'Two Models of Pluralism and Tolerance,' in Toleration: An Elusive Virtue, David Heyd, ed. (Princeton: Princeton University Press).

Larmore, Charles (1999) 'The Moral Basis of Political Liberalism,' in Journal of Philosophy, XCVI, pp. 599-625.

Mawdudi, Abul-A'la (1975) Al-Qanun al-Islami wa Turuq Tanfithih [Islamic law and methods of its application] (n.p.: Mu'assat al-Risalah).

An-Na'im, Abdullahi Ahmad (1990) Toward an Islamic Reformation: Civil Liberties, Human Rights, and International Law (Syracuse: Syracuse University Press).

O'Neill, Onora (1989) 'The Public Use of Reason,' in The Constructions of Reason (Cambridge: Cambridge University Press).

O'Neill, Onora (1997) 'Political Liberalism and Public Reason: A Critical Notice of John Rawls, Political Liberalism,' in Philosophical Review, 106, pp. 411-28.

Rawls, John (1985) 'Justice as Fairness: Political Not Metaphysical,' in Philosophy and Public Affairs, 14(3), pp. 223-51.

Rawls, John (1993) Political Liberalism (New York: Columbia University Press).

Reidy, David (2000) 'Rawls' Wide View of Public Reason: Not Wide Enough,' in Res Publica, 6, pp. 49-72.

Sadowski, Yahya (1997) 'The New Orientalism and the Democracy Debate,' in Joel Beinin and Joe Stork, eds., Political Islam: Essays from Middle East Report (London: I. B. Tauris).

Schumpeter, Joseph (1976) Capitalism, Socialism, and Democracy (New York: Harper \& Row).

Shafiq, Munir (1991) Islam in the Struggle for Civilization (Tunis: Dar al-Buraq).

Shaikhaly, Abdel-Qadir (1993) Ethics of Debate [Akhlaqiyat al-hiwar] (Amman: Dar al-Shorouq).

Solum, Lawrence B. (1994) 'Inclusive Public Reason,' in Pacific Philosophical Quarterly, 75, pp. 217-31.

Soroush, Abdul-Karim (1998) 'The Evolution and Devolution of Religious Knowledge,' in Charles Kurzman, ed., Liberal Islam: A Sourcebook (Oxford: Oxford University Press).

Williams, Andrew (2000) 'The Alleged Incompleteness of Public Reason,' in Res Publica, 6, pp. 199-211.

Wolterstorff, Nicholas (1997) 'The Role of Religion in Decision and Discussion of Political Issues,' in Robert Audi and Nicholas Wolterstorff, eds., Religion in the Public Square: The Place of Religious Convictions in Political Debate (Lanham, MD: Rowman \& Littlefield). 
Copyright $\odot 2003$ EBSCO Publishing 